Journal of Agrometeorology 23 (2) : 147-153 (June 2021)

\title{
Potential yield and yield gap analysis of sugarcane (Saccharum officinarum) using the DSSAT-CANEGRO model in different districts of Uttar Pradesh, India
}

\author{
R.S. SINGH ${ }^{* *}$, K.K. SINGH ${ }^{2}$, A.H. BHENGRA ${ }^{1}$, S.M. SINGH ${ }^{1}$, GANESHPRASAD ${ }^{1}$, PRIYANKA \\ SINGH $^{2}$, MAMTA RANA²and G.B. GOHAIN ${ }^{2}$ \\ ${ }^{1}$ Department of Geophysics, Banaras Hindu University, Varanasi 221 005, India \\ ${ }^{2} A A S$ Division, India Meteorological Department, Lodi Road, New Delhi 110003 \\ "Corresponding author : rsingh_61@yahoo.co.in
}

\begin{abstract}
DSSAT-CANEGRO model have been used to determine crop potential yield over eight districts (viz; Muzaffarnagar, Shahjahanpur, Agra, Lucknow, Basti, Faizabad, Allahabad and Jhansi) representing different agroclimatic conditions \& environmentof Uttar Pradesh state in India. The thirty six years (1980-2016) daily weather data of above districts were used to simulate seasonal yield potentials under the various management conditions and compared with the respective district reported yield. The simulated mean potential yield by the CANEGRO model over different district of the state varied between $77.8 \mathrm{t} \mathrm{ha}^{-1}$ in Muzaffarnagar and $97.8 \mathrm{t} \mathrm{ha}^{-1}$ in Agra, while mean reported yield (fresh stalk mass) varied between $40.1 \mathrm{t} \mathrm{ha}^{-1}$ in Jhansi and $62.8 \mathrm{t} \mathrm{ha}^{-1}$ in Muzaffarnagar within the state. Similarly, the attainable yield by the model was simulated lowest of $65.1 \mathrm{t} \mathrm{ha}^{-1}$ in Shahjahanpur and the highest of $73.6 \mathrm{t} \mathrm{ha}^{-1}$ in Faizabad district. The management yield gap was between 9.0 to $30.0 \mathrm{t}^{-{ }^{-1}}$ while sowing yield gap was between 7.0 to $26.0 \mathrm{t} \mathrm{ha}^{-1}$ in different districts under study. Further it is not only interesting \& surprising but also encouraging to growers that the trends in total yield gap at all the above districts in various agro-climatic zones were found decreasing (narrowed down) at the rate of $138.8-801.2 \mathrm{~kg} \mathrm{ha}^{-1}$ year $^{-1}$. Delayed planting by about 30 days in some of the districts resulted into a decrease in sugarcane yield to the tune of 106.7 to $146.7,103.3$ to 143.3 and 80.0 to $133.0 \mathrm{~kg} \mathrm{ha}^{-1}$ day $^{-1}$, respectively. Findings reveal that DSSAT crop simulation model can be an effective tool to aid in decision support system. Yield gap estimates using the past crop data and subsequent adjustment in planting window may help to achieve close to the potential yields.
\end{abstract}

Keywords: DSSAT-CANEGRO model, Uttar Pradesh, seasonal potential yield, yield gap analysis.

In India, total sugarcane production is about 355.5 million tonnes. Uttar Pradesh is the largest producer of cane among all the states in India contributing about $48 \%$ of the area and $40 \%$ of the production but its productivity is low (about $59.6 \mathrm{t} \mathrm{ha}^{-1}$ ) against the national average (about $70.3 \mathrm{t}$ ha $^{-1}$ ) productivity (Deokate, 2013).Further, the productivity of sugarcane crop must be increased substantially in the coming decades to meet energy demand driven by population \& income growth (NitiAayog 2015 and van Ittersum et al., 2013).

Sugarcane is cultivated, especially in the state of Uttar Pradesh (India), in extremely diverse hydrological, soil $\&$ climatic environments such as irrigated, rain-fed tarailands, as well as under deep-water conditions. Most of the sugarcane producing districts in the state is under assured irrigation located in tarai region. Besides several social \& other constraints, the transplanting date is largely dependent upon the harvesting time of rabi season crops like pea, potato \& wheat etc. in the sugarcane dominating regions of the state. In some districts/agro-climatic zones (ACZ), erratic \& low rainfall during monsoon season leads to drought at the grand vegetative stage, and some time, it may be damaged by submergence due to high rainfall. Patel et al. (2006) and Patel et al. (2008) analysed the yield gap in different districts of Gujarat and suggested for adjustment in planting window to provide possibilities for achieving potential yields. Aggarwal and Kalra (1994) studied the climatically potential grain yield of wheat and yield gaps in India. In this paper an attempt has been made to study the potential yield and yield gap analysis of sugarcane in different districts of Uttar Pradesh state of India using the DSSAT-CANEGRO model.

\section{MATERIALS AND METHODS}

The CANEGRO model embedded in DSSAT v4.6 (Tsuji et al., 1994),calibrated by (Bhengra et al., 2016), was 
Table 1: Input data used in the model w.r.t. representative station / district in different agro-climatic zones of Uttar Pradesh, India.

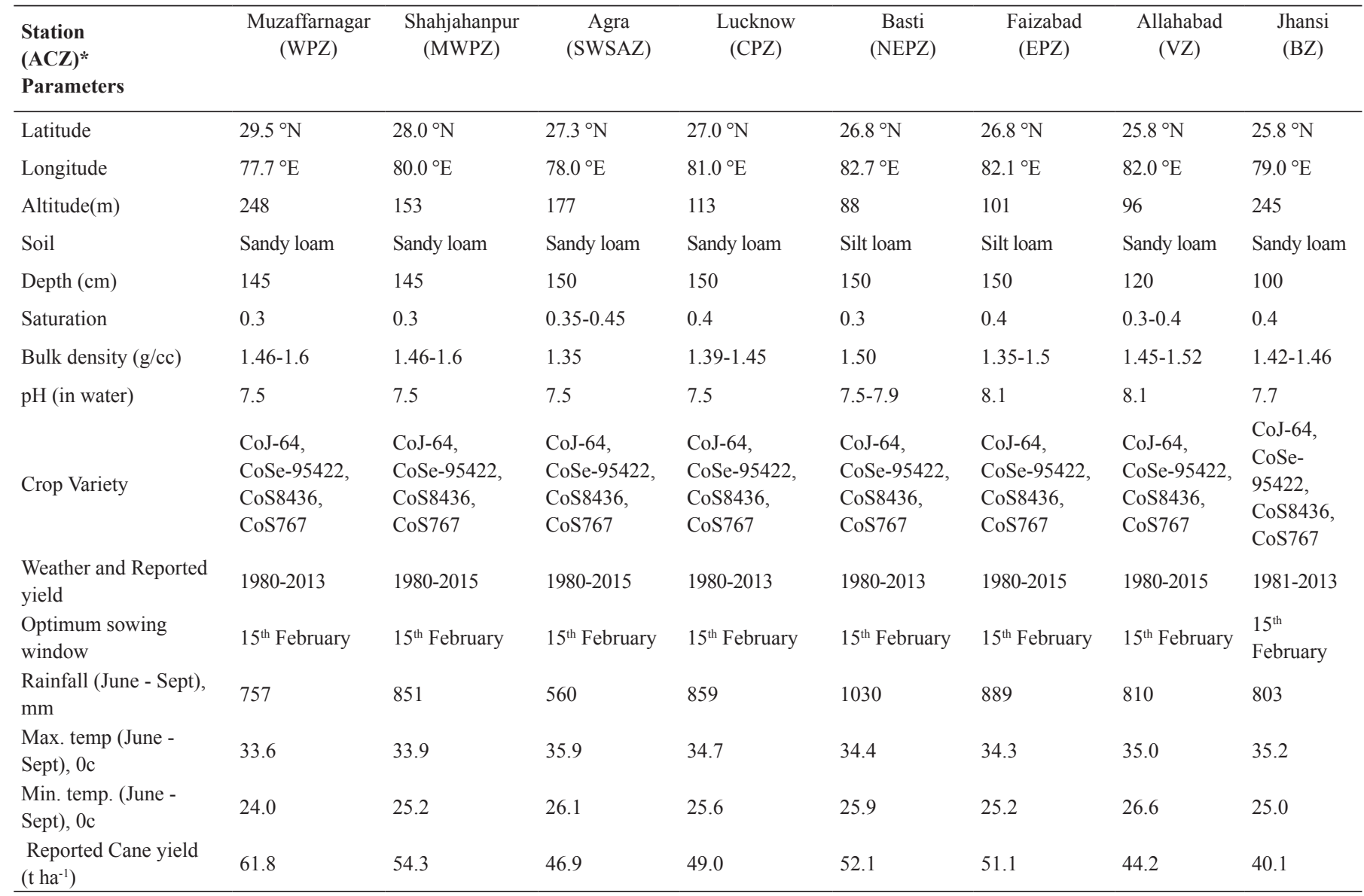

*Note-ACZ:Agro-Climatic Zone, WPZ: Western Plain Zone, MWPZ: Mid-Western Plain Zone, SWSAZ: South West Semi-Arid Zone, CPZ: Central Plain Zone, NEPZ: North East Plain Zone, EPZ: Eastern Plain Zone, VZ: Vindhyan Zone, BZ: Bundelkhand Zone.

used to simulate the potential yields of sugarcane for thirty six years (1980-2016) periods in different eight agro-climatic zones of Uttar Pradesh (India).

The corresponding daily weather data $\left(\mathrm{T}_{\max } \& \mathrm{~T}_{\min }\right.$, Rainfall and Bright Sunshine) for each station was collected from IMD, New Delhi. The districts wise sugarcane yield data for same period 1980-81 to 1915-16 was obtained from Krishi Bhawan, Lucknow. The soil information was obtained from the research stations. The details input data required to run the model are presented in Table 1. The crop genetic input data, which explains how the life cycle of a sugarcane cultivars respond to its environment; have been developed for cultivars viz. early maturing varieties CoJ $64 \&$ CoSe 95422, medium duration variety $\operatorname{CoS} 8436$ and mid-late duration CoS 767 for the period between 1980-81 and 2015-16. The model was calibrated to derive genetic coefficients of sugarcane cultivars by using field experiments data conducted during at the field sites, which were used to estimate the yield gap in sugarcane. Dates of planting for all type maturing varieties were taken starting from optimum planting date of 15 February at every 10 days interval up to 15 April. Optimum planting time was estimated based on the maximum of potential yield simulated.

The total yield gap (TYG) was calculated using difference between the actual and potential yield of sugarcane crop; the management yield gap (MYG) was calculated as the difference between attainable yield and actual yield, and the sowing yield gap (SYG) was calculated as the difference between potential yield and attainable yield.

\section{RESULTS AND DISCUSSION}

The DSSAT-CANEGRO model simulated the sugarcane productivity under various seven transplanting dates (viz. 15 ${ }^{\text {th }} \mathrm{Feb}, 25^{\text {th }} \mathrm{Feb}, 6^{\text {th }}$ March, $16^{\text {th }}$ March, 26 ${ }^{\text {th }}$ March, $5^{\text {th }}$ April and $15^{\text {th }}$ April) in the eight districts(Muzaffarnagar, 
Table 2 : Potential yields and yield gaps of sugarcane in representative districts of different ACZ of Uttar Pradesh simulated with seasonal weather for the period from 1980-81 to 2014-15.

\begin{tabular}{|c|c|c|c|c|c|c|}
\hline \multirow{2}{*}{ Parameters } & \multicolumn{3}{|c|}{ Yield $\left(\mathrm{t} \mathrm{ha}^{-1}\right)$} & \multicolumn{3}{|c|}{ Yield gap $\left(\mathrm{t} \mathrm{ha}^{-1}\right)$} \\
\hline & Potential & Attainable & Actual & Total & Management & Sowing \\
\hline \multicolumn{7}{|c|}{ Muzaffarnagar (WPZ) } \\
\hline Mean & 77.8 & 70.7 & 62.8 & 16.0 & 8.0 & 8.0 \\
\hline SD & 3.3 & 3.4 & 9.4 & 9.4 & 9.3 & 1.5 \\
\hline CV $(\%)$ & 4.2 & 4.8 & 15.0 & 62.9 & 116.9 & 21.1 \\
\hline Trend rate $\left(\mathrm{t} \mathrm{ha}^{-1} \mathrm{yr}^{-1}\right)$ & +0.0594 & +0.0851 & +0.5953 & -0.5360 & -0.4901 & -0.0258 \\
\hline $\mathrm{cc}(\mathrm{r})$ & 0.1852 & 0.2580 & $0.6493^{* *}$ & $0.5837^{* *}$ & $0.5361^{* *}$ & 0.1782 \\
\hline \multicolumn{7}{|c|}{ Shahjahanpur (MWPZ) } \\
\hline Mean & 82.6 & 65.1 & 54.3 & 28.0 & 11.0 & 17.0 \\
\hline SD & 3.3 & 4.6 & 5.9 & 7.9 & 7.9 & 5.4 \\
\hline CV $(\%)$ & 4.0 & 7.1 & 10.9 & 27.8 & 73.4 & 30.6 \\
\hline Trend rate $\left(\mathrm{t} \mathrm{ha}^{-1} \mathrm{yr}^{-1}\right)$ & -0.1447 & -0.1365 & +0.4089 & -0.5536 & -0.0082 & -0.4938 \\
\hline $\mathrm{cc}(\mathrm{r})$ & 0.301 & $0.450^{* *}$ & $0.7087^{* *}$ & $0.7213^{* *}$ & 0.0158 & $0.7196^{* *}$ \\
\hline \multicolumn{7}{|c|}{ Agra (SWSAZ) } \\
\hline Mean & 91.1 & 69.2 & 46.9 & 44.0 & 22.0 & 22.0 \\
\hline SD & 2.6 & 7.1 & 8.0 & 8.6 & 8.9 & 8.8 \\
\hline $\mathrm{CV}(\%)$ & 2.9 & 10.3 & 17.0 & 19.4 & 39.6 & 40.4 \\
\hline Trend $\left(\mathrm{t} \mathrm{ha}^{-1} \mathrm{yr}^{-1}\right)$ & -0.0929 & -0.0563 & +0.2847 & -0.3776 & -0.3410 & -0.0367 \\
\hline $\mathrm{cc}(\mathrm{r})$ & $0.3645^{*}$ & 0.0807 & $0.3669^{*}$ & $0.4490^{* *}$ & $0.3939^{*}$ & 0.0426 \\
\hline \multicolumn{7}{|c|}{ Lucknow (CPZ) } \\
\hline Mean & 85.6 & 70.0 & 49.0 & 37.0 & 21.0 & 16.0 \\
\hline SD & 12.6 & 11.7 & 7.9 & 17.0 & 15.9 & 5.6 \\
\hline CV $(\%)$ & 14.7 & 16.8 & 16.1 & 46.5 & 75.8 & 36.1 \\
\hline Trend rate $\left(\mathrm{t} \mathrm{ha}^{-1} \mathrm{yr}^{-1}\right)$ & -0.5001 & -0.3695 & +0.6695 & -0.5899 & -0.4580 & -0.1306 \\
\hline $\mathrm{cc}(\mathrm{r})$ & $0.4081^{*}$ & 0.3225 & $0.8725^{* *}$ & $0.7799^{* *}$ & $0.6493^{* *}$ & 0.2375 \\
\hline \multicolumn{7}{|c|}{ Basti (NEPZ) } \\
\hline Mean & 86.8 & 73.3 & 52.1 & 35.0 & 22.0 & 13.0 \\
\hline SD & 4.9 & 5.1 & 6.2 & 6.0 & 6.2 & 2.7 \\
\hline CV (\%) & 5.6 & 6.9 & 12.0 & 17.0 & 28.5 & 19.8 \\
\hline Trend rate $\left(\mathrm{t} \mathrm{ha}^{-1} \mathrm{yr}^{-1}\right)$ & +0.0999 & +0.1502 & +0.3708 & -0.2250 & -0.1748 & -0.0503 \\
\hline $\mathrm{cc}(\mathrm{r})$ & 0.1989 & 0.2869 & $0.6081^{* *}$ & $0.3621^{*}$ & 0.2723 & 0.1813 \\
\hline \multicolumn{7}{|c|}{ Faizabad (EPZ) } \\
\hline Mean & 87.9 & 73.6 & 51.1 & 37.0 & 23.0 & 14.0 \\
\hline SD & 2.9 & 3.0 & 6.6 & 7.7 & 7.4 & 2.6 \\
\hline CV (\%) & 3.3 & 4.1 & 12.9 & 21.0 & 32.8 & 17.9 \\
\hline Trend rate $\left(\mathrm{t} \mathrm{ha}^{-1} \mathrm{yr}^{-1}\right)$ & -0.0471 & +0.0022 & +0.455 & -0.5 & -0.37 & -0.049 \\
\hline $\mathrm{cc}(\mathrm{r})$ & 0.1642 & 0.0076 & $0.7080^{* *}$ & $0.6670^{* *}$ & $0.6109^{* *}$ & 0.1977 \\
\hline \multicolumn{7}{|c|}{ Allahabad (VZ) } \\
\hline Mean & 89.5 & 65.3 & 44.2 & 45.0 & 21.0 & 24.0 \\
\hline SD & 3.1 & 4.6 & 12.3 & 13.0 & 13.1 & 5.9 \\
\hline $\mathrm{CV}(\%)$ & 3.4 & 7.1 & 27.8 & 28.7 & 62.2 & 24.5 \\
\hline Trend rate $\left(\mathrm{t} \mathrm{ha}^{-1} \mathrm{yr}^{-1}\right)$ & -0.0135 & .0 .0040 & +0.7876 & -0.8012 & -0.7917 & -0.0095 \\
\hline $\mathrm{cc}(\mathrm{r})$ & 0.0453 & 0.0089 & $0.6576^{* *}$ & $0.6297^{* *}$ & $0.6175^{* *}$ & $0 . .0164$ \\
\hline \multicolumn{7}{|c|}{ Jhansi (BZ) } \\
\hline Mean & 95.7 & 69.8 & 40.1 & 56.0 & 30.0 & 26.0 \\
\hline SD & 3.8 & 5.7 & 8.7 & 9.0 & 14.7 & 7.4 \\
\hline CV (\%) & 3.9 & 8.2 & 21.6 & 16.2 & 53.1 & 28.6 \\
\hline Trend rate $\left(\mathrm{t} \mathrm{ha}^{-1} \mathrm{yr}^{-1}\right)$ & -0.2376 & +0.0298 & -0.0702 & -0.1388 & +0.1286 & -0.2674 \\
\hline $\mathrm{cc}(\mathrm{r})$ & 0.6287 & 0.0519 & 0.0831 & 0.1543 & 0.1305 & $0.3606^{*}$ \\
\hline
\end{tabular}

${ }^{*}$ Significant at $5 \%$ level; ${ }^{* *}$ Significant at $1 \%$ level 
Shahjahanpur, Agra, Lucknow, Basti, Faizabad, Allahabad and Jhansi) representing different agro-climatic zones. Sugarcane planting is mostly done in the spring season, which is now dominating as well as most suitable planting time in the state. Optimum yield was obtained almost at most of the district against the planting time of around middle of February $\left(15^{\text {th }}\right.$ Feb), which are considered as the optimum planting time in the state.

\section{Actual yield}

In Muzaffarnagar district of Western Plain Zone (WPZ) the sugarcane productivity was highest among all the eight districts and it ranged from 22.0 to $72.9 \mathrm{t} \mathrm{ha}^{-1}$ with mean of $62.8 \mathrm{tha}^{-1}$ and increasing trend rate of $0.60 \mathrm{t} \mathrm{ha}^{-1} \mathrm{yr}^{-}$ ${ }^{1}$ (Table 2). In Shahjahanpur district of MWPZ the sugarcane yield ranged from 41.8 to $67.6 \mathrm{t} \mathrm{ha}^{-1}$ with the mean of 54.3 $\mathrm{t} \mathrm{ha}^{-1}$ and increasing trend of $0.41 \mathrm{t} \mathrm{ha}^{-1} \mathrm{yr}^{-1}$. In Agra district of SWSAZ, the crop yield trend increased significantly in the first half of the period i.e. from 1980-81 to $1995-96$ \& afterwards it started slowly decreasing in later second half of the period. However, in general, it has ranged from 25.0 to $64.6 \mathrm{t} \mathrm{ha}^{-1}$ with mean of $46.9 \mathrm{t} \mathrm{ha}^{-1}$ and, on average, increasing trend of $0.28 \mathrm{t} \mathrm{ha}^{-1} \mathrm{yr}^{-1}$ over the entire 36-year period. In Lucknow district of Central Plain Zone (CPZ) the sugarcane fresh stalk mass ranged from 34.6 to $65.9 \mathrm{t} \mathrm{ha}^{-1}$ with mean of $49.0 \mathrm{t} \mathrm{ha}^{-1}$ and increasing trend of $0.67 \mathrm{t} \mathrm{ha}^{-1}$ $\mathrm{yr}^{-1}$. In Basti district of NEPZ located in tarai region of the state, the sugarcane yield ranged from 38.0 to $62.7 \mathrm{t} \mathrm{ha}^{-1}$ with the mean of $52.1 \mathrm{t} \mathrm{ha}^{-1}$ and increasing trend of $0.37 \mathrm{t} \mathrm{ha}^{-1} \mathrm{yr}^{-1}$. In Faizabad district of EPZ the sugarcane yield ranged from 40.2 to $66.4 \mathrm{t} \mathrm{ha}^{-1}$ with the mean of $51.1 \mathrm{t} \mathrm{ha}^{-1}$ and increasing trend rate of $0.46 \mathrm{t} \mathrm{ha}^{-1} \mathrm{yr}^{-1}$. In Allahabad district of Vindhyan agro-climatic zone, the sugarcane yield ranged from 18.1 to $68.2 \mathrm{t}$ ha- 1 with the mean of $44.2 \mathrm{tha}^{-1}$ and increasing trend of $0.79 \mathrm{t} \mathrm{ha}^{-1} \mathrm{yr}^{-1}$. In Jhansi district of Bundelkhand zone (BZ), the sugarcane productivity was lowest among all the eight districts and it ranged from 19.1 to $60.3 \mathrm{t} \mathrm{ha}^{-1}$ with mean of $40.1 \mathrm{t} \mathrm{ha}^{-1}$ and decreasing trend of about $0.10 \mathrm{t} \mathrm{ha}^{-1} \mathrm{yr}^{-1}$. Thus sugarcane productivity in seven agro-climatic zones (WPZ, MWPZ, SWSAZ, CPZ, NEPZ, EPZ \& VZ) was found to have increasing trend while in Bundelkhand zone (BZ) only, it had decreasing trend during the period (1980-81 to 201516) under the study.

\section{Potential yield}

The mean potential yield simulated by the CANEGRO- model was found to be the highest (97.8 $\mathrm{tha}^{-1}$ ) in Agra district (SWSAZ) \& ranged between 87.8 and 105.9 $\mathrm{t} \mathrm{ha}^{-1}$ during the time span of 36 year of seasonal climatic variability study. The above potential yield was about 2.1 times higher than actual yield (46.9 $\left.\mathrm{t} \mathrm{ha}^{-1}\right)$ in the district/zone (Table 2). This highest seasonal mean potential yield over Agra (SWSAZ) is followed by Jhansi $\left(95.7 \mathrm{t} \mathrm{ha}^{-1}\right)$ and Allahabad $\left(89.5 \mathrm{t} \mathrm{ha}^{-1}\right)$. The simulated potential yield in Muzaffarnagar district of Western Plain Zone was the lowest $\left(77.8 \mathrm{t} \mathrm{ha}^{-1}\right)$ followed by Shahjahanpur (82.6 $\left.\mathrm{t} \mathrm{ha}^{-1}\right)$, Lucknow (85.6 $\left.\mathrm{t} \mathrm{ha}^{-1}\right)$ and Basti $\left(86.8 \mathrm{t} \mathrm{ha}^{-1}\right)$. The actual yield is the closest to the simulated potential and attainable yield over Muzaffarnagar (WPZ) followed over Shahjahanpur (MWPZ) and Basti of NEPZ of Uttar Pradesh. This indicated that growers of these three agro-climatic zones are doing intensive sugarcane cultivation with more or less recommended agronomic \& management practices in comparison to other five (viz. SWSAZ, CPZ, EPZ, VZ \& BZ) agro-climatic zones. Above three zones are also comprising of tarai region of the state $\&$ also known for sugarcane cultivation in the state.

It may be seen from the Table 2, that the potential yields were not only higher but also more stable over 36 years period as CV per cent was less (2.9 to 14.7) in comparison to higher $\mathrm{CV}$ per cent of reported yield (4.9 to 27.8 per cent). Bhandari et al.(2002); Yadav et al.(2000) and Akula et al.(2005) also reported higher potential yield of wheat crop. This may be due to the fact that the potential conditions were assured to be free from biotic and abiotic stress (Aggarwalet al., 2008).

\section{Attainable yield}

Unlike potential yield, the simulated attainable yield was the highest $\left(73.6 \mathrm{t} \mathrm{ha}^{-1}\right)$ in Faizabad district of EPZ followed by Basti (73.3 $\mathrm{t} \mathrm{ha}^{-1}$ ) of NEPZ and Muzaffarnagar district $\left(70.7 \mathrm{t} \mathrm{ha}^{-1}\right)$ of WPZ. It was simulated the lowest attainable yield in Shahjahanpur district (65.1 $\left.\mathrm{t} \mathrm{ha}^{-1}\right)$ of MWPZ followed by Allahabad of Vindhyan Zone (65.3 $\left.\mathrm{t} \mathrm{ha}^{-1}\right)$ and Agra of South West Semi Arid Zone (68.1 t ha' ${ }^{-1}$ ). The CV per cent of attainable yield was more or less similar to that obtained for potential yield (Table 2 ). The simulation analysis revealed that there is considerable yield gap exist in sugarcane production in different districts/ACZ of Uttar Pradesh (India). Sugarcane yield could be enhanced by 43 to 63 per cent in different districts / ACZ with better management practices. It has revealed that, there is much more management crisis in the Bundelkhand Zone and adjoining areas as compared to other agro-climatic zone. 
Table 3: Reduction in potential yield $\left(\mathrm{t} \mathrm{ha}^{-1}\right)$ due to delay planting of sugarcane during spring season over different district/ $\mathrm{ACZ}$ of U.P. over the study period (1980-81 to 2014-15).

\begin{tabular}{|c|c|c|c|c|c|c|c|c|}
\hline \multirow[b]{2}{*}{ District / ACZ } & \multirow{2}{*}{$\begin{array}{c}\text { Potential } \\
\text { yield at } \\
\text { optimum } \\
\text { planting } \\
\text { time } \\
(15-\mathrm{Feb})\end{array}$} & \multirow{2}{*}{$\begin{array}{c}\text { Potential } \\
\text { yield at } 30 \\
\text { days delay } \\
\text { planting } \\
\text { (16-Mar) }\end{array}$} & \multicolumn{6}{|c|}{ Reduction in yield $\left(\mathrm{t} \mathrm{ha}^{-1}\right)$} \\
\hline & & & Range & Mean & Range (\%) & Mean $(\%)$ & $\begin{array}{c}\text { Range of } \\
\text { reduction rate } \\
\left(\mathrm{kg} \mathrm{ha}^{-1} \text { day }^{-1}\right)\end{array}$ & $\begin{array}{l}\text { Mean } \\
\text { reduction } \\
\text { rate } \\
\left(\mathrm{kg} \mathrm{ha}^{-1}\right. \\
\left.\text { day }^{-1}\right)\end{array}$ \\
\hline $\begin{array}{l}\text { Muzaffarnagar } \\
\text { (WPZ) }\end{array}$ & 79.6 & 75.9 & $(3.2-4.4)$ & 3.7 & $(3.9-5.1)$ & 4.6 & $(106.7-146.7)$ & 123.3 \\
\hline $\begin{array}{l}\text { Shahjahanpur } \\
\text { (MWPZ) }\end{array}$ & 82.4 & 78.8 & $(3.1-4.3)$ & 3.6 & $(3.6-4.8)$ & 4.4 & $(103.3-143.3)$ & 120.0 \\
\hline Agra (SWSAZ) & 91.0 & 87.7 & $(2.4-4.0)$ & 3.3 & $(2.5-4.1)$ & 3.6 & $(80.0-133.0)$ & 110.0 \\
\hline Lucknow (CPZ) & 84.7 & 81.3 & $(2.8-4.2)$ & 3.4 & $(3.1-4.6)$ & 4.0 & $(93.3-140.0)$ & 113.3 \\
\hline Basti (NEPZ) & 80.9 & 77.2 & $(3.1-4.4)$ & 3.7 & $(3.6-5.1)$ & 4.6 & $(103.3-146.7)$ & 123.3 \\
\hline Faizabad (EPZ) & 87.4 & 83.6 & $(3.2-4.6)$ & 3.8 & $(3.5-4.9)$ & 4.3 & $(106.7-153.3)$ & 126.7 \\
\hline Allahabad (VZ) & 88.5 & 85.0 & $(2.6-4.4)$ & 3.5 & $(2.8-4.6)$ & 3.9 & $(86.7-146.7)$ & 116.7 \\
\hline Jhansi (BZ) & 95.1 & 91.5 & $(2.8-4.4)$ & 3.6 & $(2.8-4.3)$ & 3.8 & $(93.3-146.7)$ & 120.0 \\
\hline $\begin{array}{l}\text { Mean for entire } \\
\text { U.P. }\end{array}$ & 86.2 & 82.6 & $(3.3-3.8)$ & 3.6 & $(3.6-4.6)$ & 4.1 & $(110.0-126.7)$ & 119.2 \\
\hline
\end{tabular}

Note: Range is computed based on simulated potential yield w.r.t. four cultivars of sugarcane (viz; CoJ 64, CoSe 95422, CoS 8436 and $\operatorname{CoS} 767)$

\section{Total yield gap (TYG)}

The total yield gap (TYG) obtained as difference between potential yield and reported yield (Table 2) suggested that the highest mean yield gap $\left(56 \mathrm{t} \mathrm{ha}^{-1}\right)$ was in Jhansi district of Bundelkhand Zone followed by Allahabad $\left(47 \mathrm{t} \mathrm{ha}^{-1}\right)$ and Agra of South West Semi Arid Zone (44 t ha $\left.{ }^{-1}\right)$. The lowest TYG $\left(16 \mathrm{tha}^{-1}\right)$ found in Muzaffarnagar district of WPZ followed by Shahjahanpur district ( $30 \mathrm{t} \mathrm{ha}^{-1}$ ) of MWPZ \& Basti district (36 $t \mathrm{th}^{-1}$ ) of NEPZ. The TYG in other two zones i.e. in Faizabad district (EPZ) was $37 \mathrm{t} \mathrm{ha}^{-1}$ and in Lucknow district (CPZ) it was $42 \mathrm{t} \mathrm{ha}^{-1}$. The coefficients of variation were between 16 to 63 per cent, suggesting higher uncertainly which is mainly attributed to higher variability in the reported yield.

\section{Management yield gap (MYG)}

The management yield gap (MYG) obtained as the difference between attainable yield and reported yield are presented in Table 2. The results show that the highest management yield gap $\left(30 \mathrm{tha}^{-1}\right)$ was in Jhansi district followed by Lucknow ( $26 \mathrm{t} \mathrm{ha}^{-1}$ ), Allahabad \& Faizabad (each $23 \mathrm{t}$ ha 1). The lowest MYG $\left(9 \mathrm{t} \mathrm{ha}^{-1}\right)$ found in Muzaffarnagar district (WPZ) followed by Shahjahanpur in MWPZ (12 $\left.\mathrm{t} \mathrm{ha}^{-1}\right)$. Further, the MYG in Agra \& Basti district of SWSAZ \& NEPZ, respectively, was $22 \mathrm{t} \mathrm{ha}^{-1}$ each. Thus there is large scope in increasing the yield through timely management of sugarcane cultivation in all the agro-climatic zones of Uttar Pradesh excepting in WPZ \& MWPZ where MYG is minimum $(9 \& 12 \mathrm{t}$ $\mathrm{ha}^{-1}$ ) and further efforts to reduce the MYG may not be justified \& economical. Therefore, for these two agro-climatic zone, further reduction in yield gap could be possible only through early planting of sugarcane around middle of Feb in place of middle of March \& onwards (after harvest of wheat crop, which delay the planting in the region).

\section{Sowing yield gap (SYG)}

The sowing yield gap is difference between potential and attainable yield due to delay planting by 15 days at least. The sowing yield gap was highest $\left(26 \mathrm{t} \mathrm{ha}^{-1}\right)$ in Jhansi district 
of Bundelkhand zone followed by Allahabad $\left(24 \mathrm{t} \mathrm{ha}^{-1}\right) \&$ Agra district $\left(22 \mathrm{t} \mathrm{ha}^{-1}\right)$ of VZ \& SWSAZ, respectively. The lowest $\left(7 \mathrm{t} \mathrm{ha}^{-1}\right)$ in Muzaffarnagar district (WPZ) followed by Basti, Faizabad district (14 $\mathrm{t} \mathrm{ha}^{-1}$ each) and Shahjahanpur district (18 $\mathrm{t}$ ha $^{-1}$ ) of MWPZ.

\section{Vield trend rates (YTR)}

The trend using the methodology of W.M.O.(1966) and Singh et al. (1999) on time series of sugarcane reported yield revealed considerably positive over seven out of above eight districts (zones) with a rate of change of $0.79,0.67,0.60$, $0.46,0.41,0.37 \& 0.28 \mathrm{tha}^{-1}$ year $^{-1}$ in Allahabad (VZ), Lucknow (CPZ), Muzaffarnagar (WPZ), Faizabad (EPZ), Shahjahanpur (MWPZ), Basti (NEPZ) and Agra (SWSAZ), respectively and it was slowly declining over Jhansi (BZ) only at the rate of $0.07 \mathrm{t} \mathrm{ha}^{-1}$ year $^{-1}$ (Table 2). In contrary to above, the trend in sugarcane potential yield revealed slight negative over six out of eight districts and with a rate of change found between 0.01 and $0.5 \mathrm{t} \mathrm{ha}^{-1}$ year $^{-1}$. The trend was apparently positive over the two zones, Muzaffarnagar (WPZ) \& Basti (NEPZ) of Uttar Pradesh with a rate of change of 0.06 and $0.1 \mathrm{t} \mathrm{ha}^{-1}$ year $^{-1}$, respectively. Similarly, trend of attainable yield was slightly decreasing over four (viz; Shahjahanpur, Agra, Lucknow\&Allahabad) and slightly increasing over remaining four districts/zones of the state. Further, the variability and trends in sugarcane yield gaps w.r.t. TYG, MYG \& SYG over 36-year periods in all the districts (Muzaffarnagar, Shahjahanpur, Agra, Lucknow, Basti, Faizabad, Allahabad and Jhansi) as a representative of different agro-climatic zones of Uttar Pradesh have been presented in Table 2. In general, the study revealed that, trends in all kinds of yield gap (viz; TYG, MYG \& SYG) is found apparently decreasing @ from 0.01 to $0.66 \mathrm{t} \mathrm{ha}^{-1}$ year $^{-1}$ at all the locations/ districts in different ACZ of the Uttar Pradesh excepting MYG at Jhansi (BZ), which increased at the linear trend rate of $0.12 \mathrm{t}$ ha $^{-1}$ year $^{-1}$ over the period of study. The total yield gap (TYG), in particular, is declining from $0.14 \mathrm{t} \mathrm{ha}^{-1}$ year $^{-1}$ at Jhansi in BZ to $0.8 \mathrm{t} \mathrm{ha}^{-1}$ year ${ }^{-1}$ at Lucknow in CPZ of the state. In other words, the trends in total yield gap (TYG) at all the agro-climatic zones were found decreasing (narrowed down) @ of 138.8-801.2 $\mathrm{kg} \mathrm{ha}^{-1}$ year ${ }^{-1}$. This decrease in yield gap is encouraging for the grower in the further improvement of yield to achieve the potential yield of the region.

\section{Effect of delayed planting on sugarcane}

There is common practice of late spring season planting of sugarcane, after the harvest of wheat crop, by the farmers of western Uttar Pradesh region comprising agro- climatic zones of Western Plain Zone (WPZ), Mid Western Plain Zone (MWPZ) \& South West Semi Arid Zone (SWSAZ). The quantified analysis of simulated sowing yield gap using the model revealed that the delay in planting of sugarcane caused reduction in yield at the rate ranging between $106.7 \& 146.7 \mathrm{~kg}$ ha $^{-1}$ day $^{-1}$ (Table 3) in Muzaffarnagar district of WPZ, 103.3 \& $143.3 \mathrm{~kg} \mathrm{ha}^{-1} \mathrm{day}^{-1}$ in Shahjahanpur district of MWPZ, as well as 80.0 \& $133.0 \mathrm{~kg} \mathrm{ha}^{-1} \mathrm{day}^{-1}$ in Agra district of SWSAZ. Singh et al. (2015 \& 2016) have reported rice sowing yield gap to the tune of 1.9 to $74 \mathrm{~kg} \mathrm{ha}^{-1} \mathrm{day}^{-1}$ at different location in India, Patel et al. (2008) have also reported wheat sowing yield gap of $18 \mathrm{~kg} \mathrm{ha}^{-1} \mathrm{day}^{-1}$ in Gujarat, and Aggarwal and Kalra (1994) have quantified wheat yield gap of $50 \mathrm{~kg} \mathrm{ha}^{-1} \mathrm{day}^{-1}$ due to delay sowing.

\section{CONCLUSIONS}

The study revealed that there is still considerable yield gap in sugarcane production over different part of Uttar Pradesh. The yield in the most part of the state could be enhanced by about 50 per cent with recommended management practices.Also, there is much more management crisis in the Bundelkhand Zone and adjoining areas as compared to other agro-climatic zone.

Further, the late spring planting mainly in the Western part of Uttar Pradesh caused reduction in simulated cane yield (a) of 80.0 to $146.7 \mathrm{~kg} \mathrm{ha}^{-1} \mathrm{day}^{-1}$. Sowing/planting time is a nonmonitory input. If properly managed, it can result significantly in yield improvement. Thus the DSSAT-CANEGRO model can be used for such decision making in crop management and improving the resource use efficiency.

\section{ACKNOWLEDGEMENTS}

Financial support provided in terms of SRF from RGNF, GOI, New Delhi to the third author is thankfully acknowledged.

\section{REFERENCES}

Aggarwal, P.K. and Kalra, N.(1994).Analyzing the limitation set by climatic factors, genotype and water and nitrogen availability on productivity of wheat II, Climatic potential yield and management strategies. Field Crops Res., 38:93-103.

Aggarwal, P.K., Hebbar, K.B., Venugopalan, M.V., Rani,S., Bala, A., Biswal, A., and Wani, S.P.(2008). Quantification of Yield Gaps in Rainfed Rice, Wheat, Cotton and Mustard in India. Global Theme on Agroecosystems 
Report no. $43 \& 36$ pages. ICRISAT, Hyderabad.

Akula, B., Sheikh, A.M., and Parmar, R.S.(2005). Estimating of variability in wheat production level in Middle Gujarat using simulation model. J. Agrometeorol., 7 (2):208-213.

Bhandari, A.L., Ladha, J.K., Pathak, H., Padre, A.T., Dawe, D. and Gupta, R.K. (2002). Trend of yield and soil nutrient status in long-term rice-wheat experiment in the IndoGangetic Plains of India.Soil Sci.Soc. Am.J., 66:162-170.

Bhengra, A.H., Yadav, M.K., Patel, Chandrabhan, Singh, P.K., Singh, K.K. and Singh, R.S. (2016). Calibration and validation study of sugarcane (DSSAT-CANEGRO V4.6.1) model over North Indian region. $J$ Agrometeorol., 18(2): 234-239.

Deokate, Tai Balasaheb (2013). Quantification of yield gaps in different planting types of sugarcane in Maharashtra. Indira Gandhi Institute of Development Research (IGIDR), Mumbai-400065, Publication no. WP2013-011, pp 86.

Niti, Aayog (2015). Raising agricultural productivity and making farming remunerative for Farmers: An occasional paper, p 46.

Patel,V.J., Patel, H.R. and Pandey V. (2008). Estimation of wheat yield gap in Anand and Panchmahal districts using CERES-wheat model. J. Agrometeorol., 10 (special issue): 393-397.

Patel, H.R. and Shekh, A.M. (2006). Yield gap and trend analysis of wheat using CERES-wheat model in three districts of Gujarat state. J. Agrometeorol., 8 (1): 2839.
Singh, P.K., Singh, K.K., Bhan, S.C., Baxla, A.K., Gupta, A., Balasubramanian, R. and Rathore, L.S. (2015). Potential yield and yield gap analysis of rice (Oryza Sativa L) in eastern and north eastern regions of India using CERES-rice model. J. Agrometeorol., 17 (2): 194-198.

Singh, P.K., Singh, K.K., Rathore, L.S., Baxla, A.K., Bhan, S.C., Gupta, A., Gohain, G.B. Balasubramanian, R., Singh, R.S. and Mall, R.K. (2016). Rice (Oryza Sativa L) yield gap using the CERES-rice model of climate variability for different agro-climatic zonesofIndia. Current Sci., 110 (3): 405-413.

Singh, R. S., Sharma, K.D. and Faroda, A. S. (1999). Climate change and its impact on drought and floods in Luni River Basin of Northwest Arid India. J. Agrometeorol., 1(2): 99-112.

Tsuji, G.Y., Uehara, G. and Balas, S. (1994). 'DSSAT version 3 Volumes 1, 2, and 3. International Benchmark Sites Network for Agrotechnology Transfer. University of Hawaii, Honolulu, Hawaii (Eds).

Van Ittersum M. K., Cassman K. G., Grassini P., Wolf G., Tittonell P., Hochman Z., (2013).Yield gap analysis with local to global relevance: a review. Field Crop Res., 143: 4-17.

World Meteorological Organisation (1966). Climate Change. WMO Technical Note No 79, WMO no 195, TP-100, Geneva, Switzerland, pp. 80.

Yadav, R.L., Diwivedi, B.S., Orsad, K., Tomar, O.K., Shurapali, N.J. and Pandey, P.S. (2000). Yield trends and changes in soil organic-C and available NPK in a long-term rice-wheat system under integrated use of manures and fertilizers. Field Crop Res., 68:219-224. 